American Journal of Animal and Veterinary Sciences 4 (1): 26-31, 2009

ISSN 1557-4555

(C) 2009 Science Publications

\title{
Plasma Catecholamines, Sweat Electrolytes and Physiological Responses of Exercised Normal, Partial Anhidrotic and Anhidrotic Horses
}

\author{
A. Bashir and A. Rasedee \\ Faculty of Veterinary Medicine, University Putra Malaysia, \\ 43000 UPM, Serdang, Selangor, Malaysia
}

\begin{abstract}
Problem statement: Malaysia imports horses from temperate countries to develop equine sports in the country. Several of these horses developed partial and complete anhidrosis. Approach: Normal, partial anhidrotic and anhidrotic horses were exercised to determine their sweating and physiological responses to exercise. The heart and respiratory rates, rectal temperature and blood samples were obtained before the horses were lunged at $10 \mathrm{~km} \mathrm{~h}^{-1}$ for $1 \mathrm{~h}$ and at again at $15,30,45,60$ min and $24 \mathrm{~h}$ after exercise. The blood adrenaline and noradrenaline concentrations were determined. Sweat samples were obtained at 60 min after exercise and analyzed for $\mathrm{Na}^{+}, \mathrm{K}^{+}, \mathrm{Cl}^{-}$, urea and total protein concentrations. Results: The normal horses sweated profusely all over the body after $5 \mathrm{~min}$ into exercise, but the partial anhidrotic horses showed sweating in the neck, brisket, shoulder, rump, perineum and axilla only after 20-30 min of exercise. The sweat $\mathrm{Na}^{+}, \mathrm{K}^{+}, \mathrm{Cl}^{-}$, urea and total protein concentrations were lower in the partial anhidrotic horses than in normal horses while the $\mathrm{Na}^{+}: \mathrm{K}^{+}$was higher. The heart and respiratory rates and rectal temperature of anhidrotic horses reached maximum values of $133.6 \pm 0.8$ beats $\mathrm{min}^{-1}$ and $186.8 \pm 0.5$ breaths $\mathrm{min}^{-1}$ and $41.1 \pm 0.0^{\circ} \mathrm{C}$ respectively and took much longer to return to resting levels than other horses. The resting adrenaline concentrations in the anhidrotic horses were higher than in partial anhidrotic and normal horses, with the mean post-exercise adrenaline: Noradrenaline consistently above 1.15 . Conclusion: The most important factor in equine anhidrosis was failure of sweat glands to respond to adrenaline. The anhidrotic horse regulated body electrolytes by means other than sweating. Anhidrotic horses exhibited exercise intolerance, particularly in hot and humid climates. There is a need to formulate a special regime for exercising anhidrotic horses in the tropical environment.
\end{abstract}

Key words: Sweat, exercise, electrolytes, catecholamines, anhidrosis, horse

\section{INTRODUCTION}

Sweating is dependent on environmental conditions. High environmental ambient temperature and humidity limit evaporative heat loss exposing the horse to the risk of thermal stress ${ }^{[1]}$. In horses, $80 \%$ of body heat is loss through evaporation via sweating mechanisms ${ }^{[2]}$. In the temperate environment sweating and heat loss through evaporation is efficient ${ }^{[3]}$. However, in the tropical environment where the relative humidity and temperature are high, evaporative cooling or sweating becomes inadequate.

Anhidrosis is most common in Thoroughbreds and may afflict horses imported into tropical and subtropical countries ${ }^{[4]}$. Although the horse body temperature at rest are well-regulated through sweating, in anhidrotic horses there is an absence of sweating, thus the body heat may need to be dissipated by other means particularly evaporation via respiration ${ }^{[2]}$. This may cause the respiratory rate to increase. As heat is accumulated as a result of inefficient loss of body heat, the tissue core temperature will also increase resulting in an increase in rectal temperature. The heart may also contribute to the dissipation of heat to the periphery by increasing its rate. Although the increase in heart rate, respiratory rate and body temperature that occur with the elevation of ambient temperature and humidity is well-documented ${ }^{[5-7]}$, the quantum of increase of these physiological parameters in exercised partial anhidrotic and anhidrotic horses is yet to be determined.

Malaysia is actively importing horses to develop equine sports in the country. A number of these horses imported from temperate countries such as New Zealand, Australia and Argentina developed anhidrosis. This study was conducted to determine the effect of exercise on the physiological responses and sweating

Corresponding Author: Prof. Rasedee Abdullah, Faculty of Veterinary Medicine, University Putra Malaysia, 43000 UPM, Serdang, Selangor, Malaysia Tel: 60389468295 Fax: 603-89468333 
characteristics of imported horses that developed partial and complete anhidrosis for purpose of formulating control and treatment of the condition.

\section{MATERIALS AND METHODS}

Five partial anhidrotic and 5 completely anhidrotic horses were selected for the study. Horses that completely failed to sweat and horses that partially produced non-foamy sweat after lunging at a speed of $10 \mathrm{~km} \mathrm{~h}^{-1}$ for 30 min were considered as anhidrotic and partial anhidrotic respectively. The selected horses were than examined to ensure that they were clinically healthy. Five normal sweating Thoroughbred horses were also selected as controls.

The environmental temperature and humidity were recorded each day of the study. The horses were lunged for $1 \mathrm{~h}$ at the $10 \mathrm{~km} \mathrm{~h}^{-1}$ at approximately the same time (9.00-10.00 am) each day. The exercise was interrupted every $15 \mathrm{~min}$ to allow the respiratory rate, heart rate, rectal temperature, sweating characteristics to be recorded and blood samples collected. Sweat samples were obtained only after $1 \mathrm{~h}$ of work.

The respiratory and heart rates, rectal temperature and sweating characteristic were observed continuously for the duration of the study period. The sweat characteristics were determined based order of intensity, that is, dry, moist, wet, foamy, dripping.

The sweat collection sites were at both left and right lateral thoracic areas caudal to the withers and 40 $\mathrm{cm}$ from the dorsal spinous process. An area of $20 \times 20$ $\mathrm{cm}$ was selected, clipped, shaved free of hair, thoroughly shampooed, rinsed well with deionised water and dried. A $10 \times 10 \mathrm{~cm}$ cotton gauze swab was attached to the skin with a dermal tape and covered with a small plastic sheet, taped firmly to the skin and anchored to the body with an elastic adhesive bandage taped along the circumference of the thoracic region. The cotton gauze was removed after $1 \mathrm{~h}$ of work and placed into a $150 \mathrm{~mL}$ bottle and capped. The gauze was than soaked in $50 \mathrm{~mL}$ sterile deionised water to extract and dilute the sweat. The $\mathrm{Na}^{+}, \mathrm{K}^{+}, \mathrm{Cl}^{-}, \mathrm{Ca}^{2+}, \mathrm{Mg}^{2+}$ and protein concentrations in the diluted sweat samples were analyzed using a chemistry analyzer (Hitachi 902).

Plasma from venous blood collected in EDTA was stored at $-30^{\circ} \mathrm{C}$ until analysis. A $500 \mu \mathrm{L}$ thawed plasma sample was transferred into a $9 \mathrm{~mL}$ ASPEC test tube and diluted to $10 \mathrm{~mL}$ with pure water. The plasma samples were applied to a Superclean TM LC-WCX (1 $\mathrm{mL}$ ) Solid Phase Extraction (SPE) columns previously conditioned with $500 \mu \mathrm{L}$ of $0.5 \mathrm{~N} \mathrm{HCl}$ at flow rates of $250 \mu \mathrm{L} \mathrm{min}{ }^{-1}$. The columns were then washed twice with one $\mathrm{mL}$ distilled water and a $250 \mu \mathrm{L}$ internal standards solution containing 480 pg 3,4dihydroxybenzylamine in water was added at a slow flow rate. The catecholamines were eluted by addition of $250 \mu \mathrm{L} 0.2 \mathrm{M} \mathrm{HClO}_{4}$ and collected in a salinized glass vial. Analyses were performed on a HPLC system consisted of Waters 590 HPLC, Waters 717 Autosampler and Waters 460 Electrochemical Detector. A volume of $50 \mu \mathrm{L}$ of eluate was injected onto a Supelcosil LC-18 DB column at a flow rate of $1.5 \mathrm{~mL} \mathrm{~min}^{-1}$.

\section{RESULTS}

The sweat was collected after the horses were lunged at the ambient temperature of $27-28^{\circ} \mathrm{C}$ and humidity of $70-75 \%$.

The normal sweating horse, dry at the beginning and within 5 min into work began to show first signs of sweating as moist skin all over the body, except the head. The head showed signs of sweating only after 10 min into work. After 15-20 min into work, the sweat droplets coalesced producing a moist appearance on all parts of the body except the neck, brisket and shoulder. In the neck, brisket and shoulder of the normal horse, sweat development was fast and the onset of sweating was seen as moist skin within 5 min into work and became wet within $10 \mathrm{~min}$. Sweat began to drip from neck, head, rump, perineum and limbs after $40 \mathrm{~min}$ of exercise. Foamy sweat began to appear at the brisket, shoulder and axilla between 10-30 min of exercise. Maximum sweating was observed after $1 \mathrm{~h}$ of exercise with the superficial skin capillaries mainly at the neck, shoulder thorax and abdomen visibly distended.

In the partial anhidrotic horses, the head, thorax, abdomen and limb of partial anhidrotic horse remained totally dry throughout the exercise period. Other parts of the body, namely the neck, brisket, shoulder, rump, perineum and axilla, showed signs of sweating as moist skin only, between 20-30 min into exercise. The brisket, shoulder, perineum, axilla and ventral area eventually became moist within 30-40 min. A slightly greater accumulation of sweat was seen as wet skin only at the axilla after 55 min of work.

The normal resting heart rate of the horses in the tropics was between $34-45$ beats $\mathrm{min}^{-1}$. The heart rates of these horses approximately doubled the resting values after 15 min of exercise. After approximately 45 min of exercise the heart rate of all horses reached maximum values (Fig. 1). The heart rate of the normal sweating horses returned to resting values $30 \mathrm{~min}$ after cessation of exercise. In the partial anhidrotic horses the return of heart rate to resting values occurred after 45 min, while in the anhidrotic normal heart it was after more than $2 \mathrm{~h}$. 
American J. Animal \& Vet. Sci., 4 (1): 26-31, 2009

Table 1: Sweat electrolyte, urea and protein concentrations in the normal, partial anhidrotic and anhidrotic horses

\begin{tabular}{llllllr}
\hline Horse & $\mathrm{Na}^{+}\left(\mathrm{mmoL} \mathrm{L}^{-1}\right)$ & $\mathrm{K}^{+}\left(\mathrm{mmoL} \mathrm{L}^{-1}\right)$ & $\mathrm{Cl}^{-}\left(\mathrm{mmoL} \mathrm{L}^{-1}\right)$ & Urea $\left(\mathrm{mmoL} \mathrm{L}^{-1}\right)$ & Total protein $\left(\mathrm{g} \mathrm{L}^{-1}\right)$ & $\mathrm{Na}^{+}: \mathrm{K}^{+}$ \\
\hline Normal & $335.4^{\mathrm{a}} \pm 0.3$ & $203.0^{\mathrm{a}} \pm 28.6$ & $343.7^{\mathrm{a}} \pm 1.9$ & $6.8^{\mathrm{a}} \pm 0.3$ & $4.2^{\mathrm{a}} \pm 0.3$ & $1.8^{\mathrm{a}} \pm 0.3$ \\
Partial anhidrosis & $232.4^{\mathrm{b}} \pm 7.7$ & $47.6^{\mathrm{b}} \pm 7.6$ & $249.3^{\mathrm{b}} \pm 28.2$ & $4.4^{\mathrm{b}} \pm 0.4$ & $1.8^{\mathrm{b}} \pm 0.9$ & $5.4^{\mathrm{b}} \pm 0.9$ \\
\hline
\end{tabular}

All values are expressed as mean \pm std. error $(n=5) ;{ }^{a, b}$ : For each parameter, means with different superscripts are significantly different $(\mathrm{p}<0.05)$; Note: Anhidrotic horses did not develop sweat

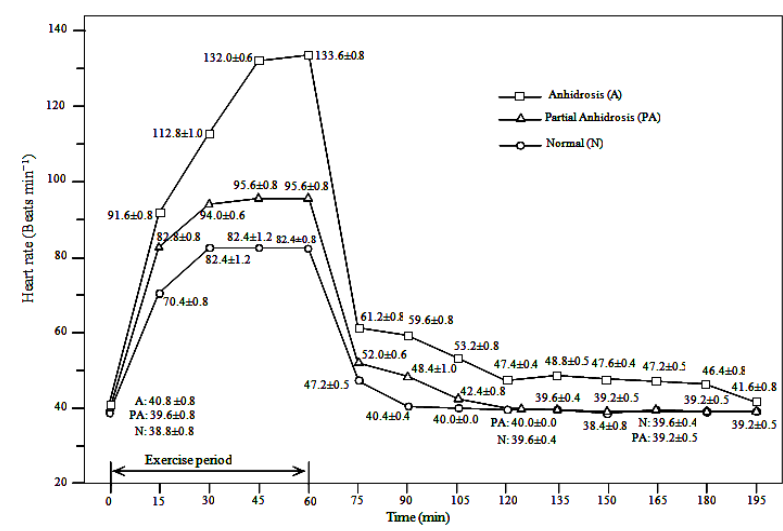

Fig. 1: Heart rate of normal sweating, partial anhidrotic and anhidrotic horses subjected to exercise

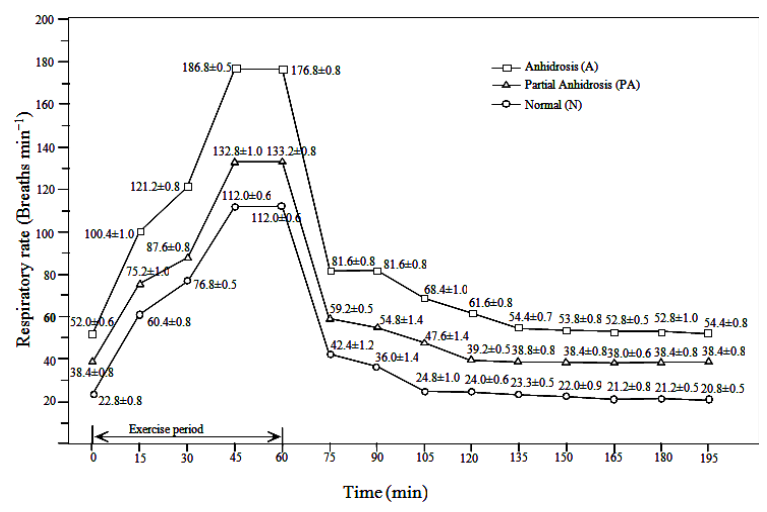

Fig. 2: Respiratory rate of normal sweating, partial anhidrotic and anhidrotic horses subjected to exercise

Both the partial anhidrotic and anhidrotic horses showed higher resting respiratory rates than the resting normal horses at 20-26 breaths $\mathrm{min}^{-1}$. With exercise the respiratory rates of these horses reached maximum after 45 min of exercise (Fig. 2). However, it took the normal horses $45 \mathrm{~min}$, partial anhidrotic $60 \mathrm{~min}$ and the anhidrotic horses $75 \mathrm{~min}$ after exercise to return to resting respiration.

The normal rectal temperature range of horses in the tropics is $37-38^{\circ} \mathrm{C}$. Although the resting rectal temperatures were similar between horses, with exercise the rectal temperature of anhidrotic horses increased at a greater rate than the other types of horses reaching a markedly higher peak after $60 \mathrm{~min}$ of exercise (Fig. 3).

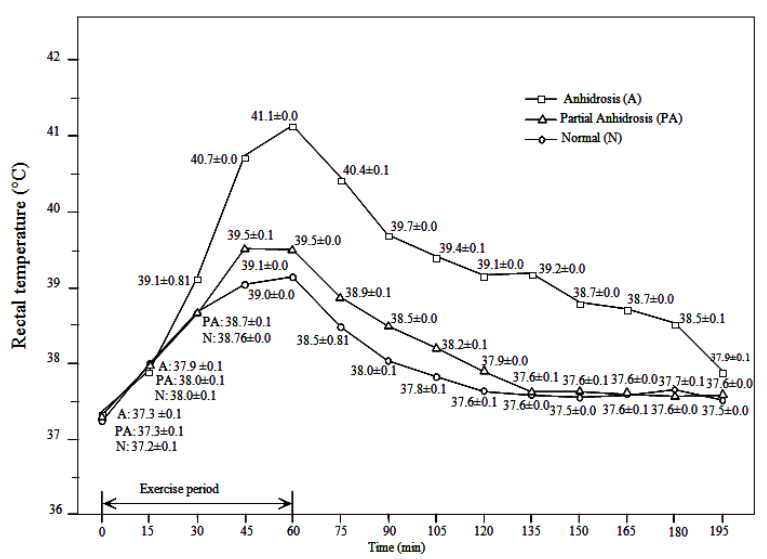

Fig. 3: Rectal temperature of normal sweating, partial anhidrotic and anhidrotic horses subjected to exercise

Table 2: Plasma noradrenaline concentration in normal sweating, partial anhidrotic and anhidrotic horses

\begin{tabular}{|c|c|c|c|}
\hline \multirow{2}{*}{$\begin{array}{l}\text { Time of } \\
\text { exercise }\end{array}$} & \multicolumn{3}{|c|}{ Noradrenaline $\left(\mathrm{nmoL} \mathrm{L}^{-1}\right)$} \\
\hline & Normal & Partial anhidrosis & Anhidrosis \\
\hline $\begin{array}{l}\text { Pre-exercise } \\
\text { Post-exercise }\end{array}$ & $4.6^{1} \pm 0.0$ & $4.7^{1} \pm 0.1$ & $4.8^{1,3} \pm 0.1$ \\
\hline $15 \mathrm{~min}$ & $4.8^{1 \mathrm{a}} \pm 0.1$ & $4.9^{2,4 \mathrm{~b}} \pm 0.1$ & $4.6^{1,3 a} \pm 0.2$ \\
\hline $30 \mathrm{~min}$ & $4.8^{1 \mathrm{a}} \pm 0.1$ & $5.2^{3 \mathrm{~b}} \pm 0.1$ & $4.8^{1,3 a} \pm 0.1$ \\
\hline $45 \mathrm{~min}$ & $4.9^{1 \mathrm{a}} \pm 0.1$ & $5.4^{3 \mathrm{~b}} \pm 0.1$ & $4.9^{2 \mathrm{c}} \pm 0.0$ \\
\hline $60 \mathrm{~min}$ & $5.0^{2 \mathrm{a}} \pm 0.1$ & $5.5^{3 \mathrm{~b}} \pm 0.2$ & $4.9^{2 \mathrm{c}} \pm 0.1$ \\
\hline $24 \mathrm{~h}$ & $4.5^{1} \pm 0.1$ & $4.6^{4} \pm 0.1$ & $4.5^{3} \pm 0.1$ \\
\hline
\end{tabular}

All values are expressed as mean \pm std. error $(\mathrm{n}=5) ;{ }^{\mathrm{a}, \mathrm{b} \text { and } \mathrm{c}}$ : For each time period (rows) means with different alphabet superscripts differs significantly $(\mathrm{p}<0.05) ;{ }^{1,2,3 \text { and } 4}$ : For each horse type (columns) means with different numerical superscipts differ significantly $(\mathrm{p}<0.05)$

The rectal temperatures of the anhidrotic horse the rectal temperature returned to normal only after $2 \mathrm{~h}$ post-exercise, compared to $75 \mathrm{~min}$ for the normal horse.

The sweat $\mathrm{Na}^{+}, \mathrm{K}^{+}, \mathrm{Cl}^{-}$, urea and protein concentrations in the partial anhidrotic were much lower $(\mathrm{p}<0.05)$ than in normal horses (Table 1$)$.

The resting adrenaline concentration in the anhidrotic horses was significantly higher $(\mathrm{p}<0.05)$ than in the partial anhidrotic and normal horses while the resting plasma noradrenaline concentrations were similar. The catecholamine concentrations increased with exercise reaching peak values after 60 min of work and returned to resting values $24 \mathrm{~h}$ after the cessation of exercise (Table 2 and 3 ). 
American J. Animal \& Vet. Sci., 4 (1): 26-31, 2009

Table 3: Plasma adrenaline concentration in normal, partial anhidrotic and anhidrotic horses

\begin{tabular}{|c|c|c|c|}
\hline \multirow{2}{*}{$\begin{array}{l}\text { Time of } \\
\text { exercise }\end{array}$} & \multicolumn{3}{|c|}{ Adrenaline $\left(\mathrm{nmoL} \mathrm{L}^{-1}\right)$} \\
\hline & Normal & Partial anhidrosis & Anhidrosis \\
\hline Pre-exercise & $4.7^{1 \mathrm{a}} \pm 0.0$ & $4.7^{1,6 \mathrm{a}} \pm 0.0$ & $5.5^{1 \mathrm{~b}} \pm 0.1$ \\
\hline Post-exercise & & & \\
\hline $15 \min$ & $5.0^{1 \mathrm{a}} \pm 0.1$ & $5.0^{2 \mathrm{~b}} \pm 0.1$ & $6.0^{2 \mathrm{c}} \pm 0.1$ \\
\hline $30 \mathrm{~min}$ & $5.3^{2 \mathrm{a}} \pm 0.2$ & $5.3^{3 \mathrm{a}} \pm 0.2$ & $5.9^{2 \mathrm{~b}} \pm 0.2$ \\
\hline $45 \mathrm{~min}$ & $5.3^{3 \mathrm{a}} \pm 0.3$ & $5.3^{4 \mathrm{a}} \pm 0.3$ & $5.8^{2 \mathrm{~b}} \pm 0.2$ \\
\hline $60 \mathrm{~min}$ & $5.5^{4 a} \pm 0.3$ & $5.5^{5 \mathrm{a}} \pm 0.3$ & $6.0^{2 \mathrm{~b}} \pm 0.3$ \\
\hline $24 \mathrm{~h}$ & $4.8^{1,5 \mathrm{a}} \pm 0.1$ & $4.8^{6 \mathrm{a}} \pm 0.1$ & $5.6^{2 \mathrm{~b}} \pm 0.2$ \\
\hline
\end{tabular}

All values are expressed as mean \pm STD. error $(n=5) ;{ }^{a, b}$ and ${ }^{c}$ : For each time period (rows) means with different alphabet superscripts differs significantly $(\mathrm{p}<0.05) ;{ }^{1,2,3}$ and 4 : For each horse type (columns) means with different numerical superscipts differ significantly $(p<0.05)$

Table 4: Plasma adrenaline: Noradrenaline ratio in normal, partial anhidrotic and anhidrotic horses

\begin{tabular}{llll}
\hline & \multicolumn{3}{l}{ Adrenaline: Noadrenaline } \\
$\begin{array}{l}\text { Time of } \\
\text { exercise }\end{array}$ & Normal & Partial anhidrosis & Anhidrosis \\
\hline $\begin{array}{l}\text { Pre-exercise } \\
\text { Post-exercise }\end{array}$ & $1.01^{\mathrm{a}} \pm 0.02$ & $1.03^{\mathrm{a}} \pm 0.05$ & $1.15^{\mathrm{b} 1} \pm 0.06$ \\
$15 \mathrm{~min}$ & $1.05^{\mathrm{a}} \pm 0.05$ & $1.07^{\mathrm{a}} \pm 0.12$ & \\
$30 \mathrm{~min}$ & $1.10^{\mathrm{a}} \pm 0.12$ & $1.01^{\mathrm{a}} \pm 0.09$ & $1.31^{\mathrm{b} 2} \pm 0.08$ \\
$45 \mathrm{~min}$ & $1.09^{\mathrm{a}} \pm 0.10$ & $1.03^{\mathrm{a}} \pm 0.03$ & $1.17^{\mathrm{b} 1,2} \pm 0.11$ \\
$60 \mathrm{~min}$ & $1.11^{\mathrm{a}} \pm 0.14$ & $1.00^{\mathrm{a}} \pm 0.04$ & $1.21^{\mathrm{b} 1,2} \pm 0.16$ \\
$24 \mathrm{~h}$ & $1.06^{\mathrm{a}} \pm 0.08$ & $1.05^{\mathrm{a}} \pm 0.09$ & $1.24^{\mathrm{b} 1,2} \pm 0.13$ \\
\hline All values are expressed as mean \pm std. error $(\mathrm{n}=5)$; $^{\mathrm{a}, \mathrm{b} \text { and }}:$ For each \\
time period (rows) means with different alphabet superscripts differs \\
significantly (p<0.05); ${ }^{1}$ and 2 : For each horse type (columns) means \\
with different numerical superscipts differ significantly ( $\mathrm{p}<0.05)$
\end{tabular}

There were only marginal differences in the plasma adrenaline: Noradrenaline between the normal sweating and partial anhidrotic horses (Table 4). However, in the anhidrotic horses, after exercise with the experimental period, the mean adrenaline: Noradrenaline ratio was consistently above 1.15 .

\section{DISCUSSION}

Equine anhidrosis is a condition seen in hot, humid environments irrespective of the region. The condition can be precipitated when horses are transported from the temperate to a tropical climate. This was observed when Thoroughbreds shipped from Britain into her tropical colonies began to lose ability to sweat ${ }^{[3]}$. These horses eventually lose the ability to sweat completely or show partial sweating at the shoulder and neck.

Anhidrotic horses are usually recognized by their partial or complete inability to sweat or show signs of partial sweating or wetting at the shoulder and neck areas. Common signs in equine anhidrosis include high respiratory rate with labored breathing, high body temperature, decreased tolerance to exercise and dry, dull and rough hair coat with alopecia especially around the face and shoulder ${ }^{[8]}$. Poor performance is one if not the most important observation in anhidrosis hence reducing the duration of the working life of racing, polo and equestrian horses. When forced into excessive work, anhidrotic horse may collapse from heat stroke. It is not uncommon for anhidrotic horses to collapse and die on the track or field after excessive work.

The pathogenesis of anhidrosis is not wellunderstood. However, previous reports have suggested several possible pathogeneses of anhidrosis including the inability of the sweat gland to respond to adrenaline $^{[3,9]}$, breakdown of sweat gland secretory apparatus $^{[10]}$, water channel impairment ${ }^{[11]}$, atrophy and hyperkeratinization of sweat glands and ducts ${ }^{[3,12]}$ and nutrition deficiencies ${ }^{[12]}$.

In this study, despite the exercise being light to medium light, changes in the heart rate, respiratory rate and rectal temperature in these horses were significant. The heart and respiratory rates and rectal temperature increased quickly in all horses, reaching peak values between 45-60 min into work. The increases were greatest in the anhidrotic horses. After 60 min of work the rectal temperature in anhidrotic horse rose to $41.1 \pm 0.04^{\circ} \mathrm{C}$. These values were at the high critical levels of approximately $41.0^{[5]}$. At this rectal temperature, a state of hyperthermia is reached, although signs of hyperthermia may or may not occur. The high rectal temperature reflects the absence of heat dissipation mechanism through sweat.

The heart rate is one of the indicators of fitness ${ }^{[13,14]}$. As the horse gets fitter the maximum heart rate decreases. Stabilization of both the heart and respiratory rates midway into work and speed of recovery from exercise also reflect fitness of horses ${ }^{[15]}$. Our study showed that the partial anhidrotic and anhidrotic horses had higher maximum heart and respiratory rates than the normal sweating horses. In the normal sweating horses, after the cessation of exercise, the heart rate returned to resting values by $30 \mathrm{~min}$, respiratory rate by $75 \mathrm{~min}$ and rectal temperature by 30 min post-exercise. As expected, the anhidrotic horse took longer to reach resting values than the normal sweating and partial anhidrotic horses. The respiratory and heart rates attained resting values by $105 \mathrm{~min}$ and $135 \mathrm{~min}$, respectively. The anhidrotic horses are deemed to be unfit for strenuous exercise in the hot humid environment.

The sweat $\mathrm{Na}^{+}, \mathrm{K}^{+}, \mathrm{Cl}^{-}$, urea and total protein concentrations were lower in the partial anhidrotic horses than in normal horses while the $\mathrm{Na}^{+}: \mathrm{K}^{+}$was higher. However, the sweat of these horses in the tropics has higher electrolyte contents than their counterparts in the temperate environment ${ }^{[16]}$. This 
result suggests that horses developing anhidrosis loses body electrolytes by other means rather than sweating.

Sweat production in horses is regulated by the $\beta_{2}$ receptors in the sweat glands ${ }^{[8]}$. In our study the adrenaline concentrations were generally higher in anhidrotic horses than the normal sweating and partial anhidrotic horses. What this implies is that the sweat glands in anhidrosis may be insensitive to adrenaline because of either the threshold concentration for sweat production had increased significantly or there is sweat gland dysfunction. The failure of sweat glands to respond to adrenaline therefore, may be the single most important factor in anhidrosis.

Due to the unknown etiology but known contributing factors, various treatments have been instituted to anhidrotic horses with variable responses. In certain cases, reduced concentrate feeding, vitamin $\mathrm{E}$ injection and fluid and electrolyte injections have been used in the treatment with encouraging results, although not conclusive ${ }^{[8]}$. All anhidrotic horses do however respond satisfactorily when moved from the hot and humid environment to a cooler climate with lower humidity or if they are stabled in a controlled environment with air-conditioning.

\section{CONCLUSION}

The most important factor in equine anhidrosis is failure of sweat glands to respond to adrenaline. The anhidrotic horse regulates body electrolytes by means other than sweating. This study also showed that anhidrotic horses exhibited intolerance to work showing slow recovery from exercise. Thus there is a need to formulate a special regime for exercising anhidrotic horses in the tropical environment, taking into consideration the environmental temperature and humidity.

\section{REFERENCES}

1. Hodgson, D.R., R.E. Davis and F.F. McConaghy, 1994. Thermoregulation in the horse in response to exercise. Br. Vet. J., 150: 219-235. http://www.ncbi.nlm.nih.gov/pubmed/8044664

2. Jenkinson, D.M., H.Y. Elder and D.L. Bovell, 2007. Equine sweating and anhidrosis. Part 1; equine sweating. Vet. Dermatol., 17: 362-392. DOI: $10.1111 / \mathrm{j} .1365-3164.2006 .00545 . \mathrm{x}$

3. Warner, D.H. and I.G. Mayhew, 1983. Equine anhidrosis: A review of pathophysiologic mechanisms. Vet. Res. Commun., 6: 249-264. http://www.springerlink.com/content/prn5t7181753 r2pq/fulltext.pdf
4. Loving, N.S., 2009. The horse: Failure to sweat. http://www.thehorse.com/ViewArticle.aspx?ID=67 $18 \& \mathrm{nID}=7 \& \mathrm{src}=\mathrm{RA}$

5. Evans, D.L. and R.J. Rose, 1988. Cardiovascular and respiratory responses to submaximal exercise training in the thoroughbred horse. J. Exp. Biol., 134: 397-408. http://jeb.biologists.org/cgi/reprint/134/1/397.pdf

6. Geor, R.J., L.J. McCutcheon, G.L. Ecker and M.I. Lindinger, 2000. Heat storage in horses during submaximal exercise before and after humid heat acclimation. J. Applied Physiol., 89: 2283-2293. http://jap.physiology.org/cgi/content/full/89/6/2283

7. Beatty, D.T., A. Barnes, E. Taylor, D. Pethick, M. McCarthy and S.K. Maloney, 2006. Physiological responses of Bos taurus and Bos indicus cattle to prolonged, continuous heat and humidity. J. Anim. Sci., 84: 972-985. http://jas.fass.org/cgi/content/full/84/4/972

8. Mayhew, I.G. and H.O. Ferguson, 1987. Clinical, clinicopathologic and epidemiologic features of anhidrosis in central Florida Thoroughbred horses. J. Vet. Intern. Med., 1: 136-141. DOI: 10.1111/j.1939-1676.1987.tb02001.x

9. Jenkinson, D.M., H.Y. Elder and D.L. Bovell, 2007. Equine sweating and anhidrosis. Part 2; anhidrosis. Vet. Dermatol., 18: 2-11. DOI: 10.1111/j.1365-3164.2007.00571.x

10. Wilson, D.C.S., A.D. Corbett, C. Steel, R. Pannirselvam and D.L. Bovell, 2007. A preliminary study of the short circuit current $\left(\mathrm{I}_{\mathrm{sc}}\right)$ responses of sweat gland cells from normal and anhidrotic horses to purinergic and adrenergic agonists. Vet. Dermatol., 18: $\quad 152-160$. DOI: $10.1111 / \mathrm{j} .1365-$ 3164.2007.00585.x

11. Bovell, D.L., S.L. Lindsay, A.D. Corbett and C. Stell, 2006. Immunolocalization of aquaporin-5 expression in sweat gland cells from normal and anhidrotic horses. Vet. Dermatol. 17: 17-23. DOI: 10.1111/j.1365-3164.2005.00498.x

12. Hein, J., 2009. Anhidrosis in horses. http://www.myhorse.com/health/emergency/anhidr osis_in_horses.aspx\#top

13. Geor, R., 2000. Peak fitness. http://www.thehorse.com/ViewArticle.aspx?ID=150

14. Freeman, D.W., D.R. Topliff and M.A. Collier, 2007. Monitoring fitness of horses by heart rate. Oklahoma cooperative extension service, ANSI 9118. (2009).

http://pods.dasnr.okstate.edu/docushare/dsweb/Get/ Document-2078/ANSI-9118web.pdf 
15. Rose, R.J., 1982. An evaluation of heart rate and respiratory rate recovery for assessment of fitness during endurance exercise. Proceeding of the 1st International Conference on Equine Exercise Physiology, (ICEEP'82), San Diego, USA., pp: 505509.

http://www.iceep.org/pdf/iceep1/_1201142134_001.pdf
16. McCutcheon, L.J., R.J. Geor, G.L. Ecker and M.I. Lindinger, 1999. Equine sweating responses to submaximal exercise during 21 days of heat acclimation. J. Applied Physiol., 87: 1843-1851. http://jap.physiology.org/cgi/content/full/87/5/1843 